\title{
Alcohol Drinking Problems Among New York City Residents after the September 11 Terrorist Attacks
}

\author{
D. VLAHOV $, 1,2,3$ S. GALEA, ${ }^{1,3}$ J. AHERN, ${ }^{1}$ S. RUDENSTINE, ${ }^{1}$ \\ H. RESNICK, ${ }^{4}$ D. KILPATRICK, ${ }^{4}$ AND R. M. CRUM ${ }^{2}$ \\ ${ }^{1}$ Center for Urban Epidemiologic Studies, New York Academy of Medicine, \\ New York, NY, USA \\ ${ }^{2}$ Department of Epidemiology, Johns Hopkins University Bloomberg School of \\ Public Health, Baltimore, MD, USA \\ ${ }^{3}$ Department of Epidemiology, Columbia University Mailman School of Public \\ Health, New York, NY, USA \\ ${ }^{4}$ National Crime Victims' Research and Treatment Center, Medical University of \\ South Carolina, Charleston, SC, USA
}

\begin{abstract}
Recent studies have shown an increase in alcohol use in New York City in the months after the September 11 terrorist attacks; thus far there have been no studies documenting changes in drinking problems. In 2002, a random digit dial phone survey was conducted of residents of New York City. This study provided us with estimates of the prevalence of alcohol drinking problems among residents of New York City 6 months after September 11 compared with the 6 months before September 11 . Among 1,570 adults, the prevalence of drinking problems was 3.7\% in the 6 months before September 11 and $4.2 \%$ in the 6 months after September 11. The incidence of drinking problems among those without drinking problems before September 11 was $2.2 \%$. Persons with incident drinking problems were more likely than those without to report symptoms consistent with posttraumatic stress disorder $(17.4 \%$ vs. $0.4 \%$ in those without drinking problems and $1.4 \%$ in nondrinkers), and depression (23.5\% vs $5.6 \% \mathrm{vs} .4 .9 \%$, respectively) after September 11. After a disaster, a link between drinking problems and posttraumatic stress disorder or depression should be assessed.
\end{abstract}

Keywords alcohol; depression; disaster; epidemiology; posttraumatic stress disorder, substance use

\section{Introduction}

Numerous studies have shown that the survivors of disasters bear a substantial burden of mental health problems (Green, 1991). Posttraumatic stress disorder (PTSD), depression, and anxiety are the most frequently documented psychological sequelae of disasters and mass trauma (Kilpatrick et al., 2003; Norris, 1992; Smith et al., 1990). Substance use is a well-documented comorbid factor accompanying PTSD and other psychological disorders (Acierno et al., 1996; Deering et al., 1996; Gleser and Green, 1981; Kessler et al., 1995). However, few investigations have specifically documented the prevalence of increased

Address correspondence to David Vlahov, Ph.D., Center for Urban Epidemiologic Studies Room 556, New York Academy of Medicine, 1216 Fifth Avenue, New York, NY 10029-5283. E-mail: dvlahov@nyam.org 
substance use in general or problems with alcohol or drinking problems in particular after major disasters. Most of the research that has examined substance use after disasters has focused on survivors of the disaster, that is, people who were in some way victims of the event (Abrahams et al., 1976; Joseph et al., 1993; Logue et al., 1993). However, persons in a community exposed to a large-scale disaster may be affected to different degrees by the disaster event, (i.e., by being present at the disaster site, through relationships with victims, disruption of personal routines, or through repeated exposure to the event through the media), suggesting that persons in the general population may also have psychological consequences and potentially attendant elevations in substance use and related problems after a disaster. For a comprehensive review about the consequences of disasters, including substance use, we refer the reader to the work of Norris and colleagues (2003a, b).

The terrorist attacks of September 11, 2001 were the largest ever human-made disaster in the United States. These attacks produced the largest death toll of any disaster on U.S. soil since the Civil War. In New York City (NYC) alone, close to 2,800 people died and a large area of lower Manhattan was destroyed in the attacks. Early studies of the acute psychological effects after the September 11 attacks suggested a high prevalence of stress, PTSD, and depression throughout the United States and particularly in Manhattan (Galea et al., 2002a; Schlenger et al., 2002; Schuster et al., 2001; Silver et al., 2002). Although follow-up studies suggested that there already was substantial resolution in populationbased PTSD and depression among NYC residents 6 months after September 11, the prevalence of these disorders remained elevated beyond baseline when measured 1 year after the attacks (Galea et al., 2003).

Use of substances might also increase after disasters (Jacobsen et al., 2001; Stewart et al., 1998). Persons who experience major trauma may use substances to relax and cope with stress and negative affect. Persons with anxiety disorders (e.g., PTSD) may suffer exacerbated withdrawal symptoms, particularly irritability or nervousness. Persons with PTSD or depression might use drugs in an attempt to self-medicate symptoms. Also, once psychopathology has developed, substance use could exacerbate symptomatology, interfering with the resolution of the traumatic experience and prolonging symptoms after the disaster.

Earlier, we reported increased prevalence of cigarette, alcohol, and marijuana use in the general population of Manhattan 1 month after September 11 and a persistent increase in substance use in NYC overall 6 months after September 11 (Vlahov et al., 2001, 2002). These increases in substance use may plausibly translate into an increase in substance use problems. As such, in this report we focus on the prevalence and incidence of alcohol drinking problems in the general population of NYC 6 months after September 11. We assessed the prevalence of drinking problems in the first 6 months after September 11 and the extent to which such problems in this time frame were associated with exposure to the events of September 11 and subsequent psychopathology.

\section{Methods}

\section{Sample}

We conducted a random digit dial household telephone survey from March 25 to June 25, 2002. The sampling frame for the survey included all adults in the NYC metropolitan area with over-sampling of residents of NYC to permit comparison with the earlier surveys. We report here results of the subsample that was within NYC boundaries. The overall 
cooperation rate for the NYC subsample was $60 \%$. Sampling weights were developed and applied to our data to correct potential selection bias related to the number of household telephones, persons in the household, and over-sampling. Further details about the numbers of persons called for this study are given elsewhere (Galea et al., 2004).

\section{Data Collection}

Trained staff conducted all interviews using a computer-assisted telephone interview system, making calls primarily on evenings and weekends. Interviews were available in English, Spanish, and Chinese. Native English, Spanish, Mandarin, and Cantonese speakers administered the interviews in the respective languages. The survey was approximately 35 minutes long. A protocol was in place to assist participants who requested mental health counseling in each of the surveys. The institutional review board of the New York Academy of Medicine approved these studies. Further discussion about how this study was established and the peculiarities of establishing rapid postdisaster research are given elsewhere (Galea et al., 2002c).

Respondents were asked questions using a structured questionnaire. The primary outcome variable for this report was participants' problems with alcohol use, hereafter referred to as "drinking problems" (which is to be distinguished from problem drinking that refers to high frequency drinking). For this, we started with the CAGE questionnaire, described elsewhere, which includes four questions that have been shown to have reasonable predictive power for alcohol drinking problems (Chan et al., 1994; Poulin et al., 1997). Although the original instrument referred to lifetime recall, we modified this instrument to reflect problems within the prior 6 months only to be relevant for noting changes in time frames of this study. We used two positive responses as a cutoff to indicate alcohol drinking problems for the purposes of these analyses. We related these questions to two time frames: in the 6 months before September 11 and in the interval between September 11 and the interview. In addition, we included questions about quantity of alcohol drinking in the month before September 11 and in the month before the survey. For participants who had ever used alcohol, we asked on how many days they had used alcohol during the month before September 11 and on those days, how many drinks (beer, wine, liquor) they consumed; we asked about all alcohol beverages as a whole in the same question. We asked identical questions for the month before the survey.

The remainder of the survey instrument was based on items from previous surveys that assessed mental health consequences of disasters (Freedy et al., 1993). Demographic variables included age, race/ethnicity, gender, yearly household income, education, and marital status. We assessed proximity to the disaster site by collecting information about where the respondent was living before September 11 and where the respondent was upon hearing about the September 11 attack. We asked about a range of September 11 event experiences, including if the respondents had witnessed the attacks of September 11, if the respondent was afraid for her or his life during the attacks, if friends or relatives were killed during the attacks, if the respondent was displaced from home as a result of the attacks, if the respondent was involved in the rescue efforts, and if the respondent lost a job or possessions as a result of the September 11 attacks. We measured perievent panic attack using a modified version of the Diagnostic Interview Schedule for panic attack (phrased to detect symptoms that happened during or shortly after the September 11 terrorist attacks) (CDC, 1989). We asked about panic symptoms specifically "in the first few hours" after the events of September 11. Consistent with DSM-IV criteria for panic attacks, the presence of 
four or more symptoms contributed to a diagnosis of perievent panic attacks (APA, 1995). In addition, we assessed prior stressors, stressors since September 11 and current supports. We asked about a list of eight traumatic events (e.g., having a spouse die, having problems at work) that the respondent had lifetime and in the year before and also since the events of September 11 (Freedy et al., 1993). For the analyses, we divided responses into groups of 0,1 , or 2 or more past-year stressors. We also used a modified version of a standard scale to measure level of social support (Resnick et al., 1993).

We used three measures of mental health status: PTSD, subsyndromal PTSD, and major depression. The PTSD measure was a modified version of the NWS (National Womens Study) PTSD Module based on the Diagnostic and Statistical Manual of Mental Disorders, third revised edition (APA, 1995; Resnick et al., 1993). The PTSD scale used has a sensitivity of $98.8 \%$ and a specificity of $79.1 \%$ when compared with structured clinical interviews (Kilpatrick et al., 1998). Further details of the PTSD and depression measures used are given elsewhere (Galea et al., 2002a, b; Kilpartick et al., 1998). In brief, to meet criteria for PTSD, participants had to report at least one reexperiencing symptom (criterion B, e.g., recurrent intrusive memories, distressing dreams), three avoidance symptoms (criterion C, e.g., efforts to avoid thoughts associated with the trauma, loss of interest in significant activities), and two hyperarousal symptoms (criterion D, e.g., difficulty falling asleep or concentrating). We also calculated the prevalence of subsyndromal PTSD based on Blanchard (Blanchard et al., 1995, 1997), that is persons who had symptoms consistent with criterion B and either criterion $\mathrm{C}$ or D were classified as having subsyndromal PTSD.

\section{Statistical Analyses}

We report prevalence and incidence of alcohol problem drinking using the modified CAGE questionnaire 6 months before and 6 months after the September 11 attacks. We used a cutoff of two or more positive responses to the modified CAGE questionnaire items, based on literature that suggests that this cutoff has the highest sensitivity and specificity in screening for alcohol use disorders (Buchsbaum et al., 1991). Two-tailed chi-square tests were used to detect associations between new-onset problem alcohol drinking, current (i.e., within past month at time of interview) PTSD, and current depression. New-onset problem alcohol drinking was cross-tabulated by each of the other covariates of interest. Crude odds ratios (ORs) and 95\% confidence intervals (CIs) were calculated for all bivariate associations. Variables that were associated with drinking problems $(p<.1)$ in bivariate analyses were included in the final multiple logistic regression models, allowing us to assess for potential confounders and to examine interaction. All calculated $p$ values were two tailed, and 95\% CIs were used to guide interpretation. We used SUDAAN for all analyses to estimate standard errors and to correct statistical tests for weighting (Shah et al., 1997).

\section{Results}

Among 1,570 NYC adults surveyed 6 months after September 11, 55.9\% of the sample were women, mean age was 42 years (standard deviation $=15.4$ years), and $35.8 \%$ were White, 28.7\% were Hispanic, and 25.7\% were African American. Age, gender, race, and residence distributions in our sample were comparable with estimates obtained by the 2000 U.S. Census for our sampling frame.

The prevalence of drinking problems for two approximately 6-month intervals (the 6 months before September 11 and the interval between September 11 and the interview) 
were calculated. Among New Yorkers, 42 participants $(2.0 \%$; 95\% CI $=1.1 \%, 3.0 \%)$ reported drinking problems before and after September 11, $46(2.2 \% ; 95 \% \mathrm{CI}=1.1 \%$, $3.2 \%)$ after but not before September 11, $22(1.7 \%$; 95\% CI $=0.8 \%, 2.6 \%)$ before but not after September 11, and $741(40.5 \%$; $95 \% \mathrm{CI}=36.6 \%, 44.3 \%)$ were consistently without drinking problems, whereas 707 (53.6\%; 95\% CI $=49.7 \%, 57.6 \%)$ reported being nondrinkers in both intervals. (Incidentally, the mean number of drinks per month for these five groups was 58, 25, 35, 10, and 0 before and 64, 34, 30, 12, and 0 after September 11, respectively.) Converting these categories to prevalence and incidence, the overall prevalence of persons with drinking problems was $3.7 \%(95 \% \mathrm{CI}=2.4 \%, 5.1 \%)$ in the 6 months before September 11 and $4.2 \%(95 \% \mathrm{CI}=2.8 \%, 5.6 \%)$ in the period after September 11. The incidence after September 11 among those without problems (including those with either no problems or use) before September 11 was $2.2 \%$ (95\% CI $=1.1 \%$, $3.3 \%$ ). Among those with drinking problems in the 6 months before September 11, one third did not have drinking problems or use after September 11. The absolute number of new cases of drinking problems was double that of those who resolved problem drinking after September 11 (i.e., $\mathrm{n}=46$ vs. 22, respectively).

The association between PTSD and depression by patterns of drinking problems were summarized for two intervals, namely "anytime since September 11" and "current," which reflects the interval in the month before the interview. Starting with symptoms anytime since September 11, those with drinking problems after September 11 were more likely than those without drinking problems after September 11 to have symptoms consistent with PTSD (i.e., PTSD rates for "before and after" $=34.2 \%$, "after but not before" $=28.4 \%$, "before but not after" $=15.4 \%$, "without drinking problem" $=5.1 \%$, and "nondrinker" = $7.0 \%)$. A similar pattern emerged for subsyndromal PTSD (48.9\%, 29.1\%, 50.0\%, 14.4\%, and $15.0 \%$, respectively) and depression $(25.7 \%, 26.3 \%, 36.6 \%, 11.2 \%$ and $10.4 \%$, respectively) anytime since September 11.

Likewise, when considering current (i.e., past month) symptoms of PTSD, the prevalence of PTSD was lower than for any time since September 11 [(reflecting resolution of PTSD (Galea et al., 2003)] but the association of current PTSD with the five drinking problem categories $(9.5 \%, 17.4 \%, 1.1 \%, 0.4 \%$, and $1.4 \%$, respectively) and current subsyndromal PTSD was still evident. However, this resolution was not as clear in cases of current depression. Higher prevalence of depression was seen among those who changed from either nonproblem to problem or from problem to nonproblem drinking $(23.5 \%$ and $28.3 \%$, respectively) followed by persons with consistent drinking problems (10.0\%), those without drinking problems (5.6\%), and nondrinkers (4.9\%). As the frequency of PTSD for past month was infrequent, the remainder of analyses refers to anytime since September 11.

Tables 1-3 show bivariate associations between demographics, stressors, and event exposure covariates and the new onset of drinking problems since September 11 among those who did not report drinking problems or use before September 11. The covariates associated with new onset drinking problems in bivariate logistic regression models (allowing $p<.10)$ were less than 25 years of age $(p<.001)$, low income $(p=.08)$, marital status $(p<.001)$, perievent panic attack $(p=.02)$, lost possessions $(p=.10)$, and lost job due to the September 11 attacks $(p=.06)$. Persons who were directly affected by the attacks (defined as having been in the buildings or injured in the attacks, having a friend or relative killed, possessions lost or damaged, lost job as a result of the attacks, or involved in rescue effort) were suggestive as more likely than those not directly affected to report new onset problem drinking; however, these results were not statistically significant. 
Table 1

Incident problem drinking by demographic characteristics among adult New York City residents categorized as without problem drinking before September 11, 2001

\begin{tabular}{|c|c|c|c|c|c|}
\hline & $\begin{array}{c}\text { Total } \\
\text { sample } \mathrm{n}\end{array}$ & $\begin{array}{c}\text { New drinking } \\
\text { problem after } \\
\text { September } 11 \\
\mathrm{n}\left(\%^{a}\right)\end{array}$ & OR & $\begin{array}{l}\text { Chi square } \\
p \text { value }\end{array}$ & $95 \% \mathrm{CI}$ \\
\hline Total & 1,494 & $42(2.21)$ & & & \\
\hline \multicolumn{6}{|l|}{ Age } \\
\hline $18-24$ & 153 & $10(7.02)$ & 1.00 & \multirow[t]{6}{*}{$<.001$} & - \\
\hline $25-34$ & 390 & $13(2.45)$ & 0.33 & & $.09-1.23$ \\
\hline $35-44$ & 307 & $11(1.54)$ & 0.21 & & $.04-.98$ \\
\hline $45-54$ & 272 & $8(.69)$ & 0.09 & & $.02-.42$ \\
\hline $55-64$ & 168 & $3(1.27)$ & 0.17 & & $.03-.90$ \\
\hline $65+$ & 186 & $1(.04)$ & 0.00 & & $.00-.04$ \\
\hline \multicolumn{6}{|l|}{ Gender } \\
\hline Male & 649 & $20(1.63)$ & 1.00 & \multirow[t]{2}{*}{.36} & - \\
\hline Female & 845 & $26(2.7)$ & 1.67 & & $.56-4.99$ \\
\hline \multicolumn{6}{|l|}{ Race/ethnicity } \\
\hline White & 733 & $22(1.49)$ & 1.00 & \multirow[t]{5}{*}{.45} & - \\
\hline Black & 249 & $6(3.21)$ & 2.19 & & $.56-8.50$ \\
\hline Asian & 118 & $6(5.28)$ & 3.68 & & $.75-18.01$ \\
\hline Hispanic & 319 & $10(2.02)$ & 1.36 & & $.37-5.05$ \\
\hline Other & 47 & $2(1.1)$ & 0.73 & & $.09-5.91$ \\
\hline \multicolumn{6}{|l|}{ Income } \\
\hline$\$ 10,000+$ & 217 & $6(4.04)$ & 1.00 & \multirow[t]{7}{*}{$<.001$} & - \\
\hline$\$ 75,000-\$ 99,999$ & 118 & $3(.19)$ & 0.05 & & $.01-.36$ \\
\hline$\$ 50,000-\$ 74,999$ & 203 & $7(1.03)$ & 0.25 & & $.03-2.05$ \\
\hline$\$ 40,000-\$ 49,999$ & 105 & $3(3.9)$ & 0.96 & & $.09-10.42$ \\
\hline$\$ 30,000-\$ 39,999$ & 150 & $7(3.39)$ & 0.83 & & $.11-6.20$ \\
\hline$\$ 20,000-\$ 29,999$ & 152 & $3(.9)$ & 0.21 & & $.02-1.93$ \\
\hline$<\$ 20,000$ & 286 & $14(5.02)$ & 1.26 & & $.20-7.85$ \\
\hline \multicolumn{6}{|l|}{ Low income } \\
\hline$\$ 20,000+$ & 945 & $29(2.03)$ & 1.00 & \multirow[t]{2}{*}{.08} & - \\
\hline$<\$ 20,000$ & 286 & $14(5.02)$ & 2.55 & & $.90-7.20$ \\
\hline \multicolumn{6}{|l|}{ Education } \\
\hline Graduate degree & 268 & $5(.97)$ & 1.00 & \multirow[t]{5}{*}{.51} & - \\
\hline College degree & 479 & $18(1.62)$ & 1.69 & & $.29-9.92$ \\
\hline Some college & 257 & $10(3.94)$ & 4.21 & & $.66-26.95$ \\
\hline High school graduate & 284 & $6(1.75)$ & 1.83 & & $.27-12.58$ \\
\hline $\begin{array}{l}<\text { High school } \\
\text { graduate }\end{array}$ & 199 & $7(2.57)$ & 2.71 & & $.37-19.87$ \\
\hline
\end{tabular}

${ }^{a}$ Weighted prevalences; see Methods. 
Table 2

Incident drinking problem by social support and stressors among adult New York City residents categorized as without problem drinking before September 11, 2001

\begin{tabular}{|c|c|c|c|c|c|}
\hline & $\begin{array}{c}\text { Total } \\
\text { sample } \mathrm{n}\end{array}$ & $\begin{array}{c}\text { New drinking } \\
\text { problem after } \\
\text { September } 11 \\
\mathrm{n}\left(\%^{a}\right)\end{array}$ & OR & $\begin{array}{l}\text { Chi } \\
\text { square } p \\
\text { value }\end{array}$ & $95 \% \mathrm{CI}$ \\
\hline Total & 1,494 & $46(2.21)$ & & & \\
\hline \multicolumn{6}{|l|}{ Marital status } \\
\hline Married & 519 & $11(.3)$ & 1.00 & \multirow[t]{3}{*}{$<.001$} & - \\
\hline Single $^{b}$ & 310 & $5(1.00)$ & 3.38 & & $.71-16.05$ \\
\hline Unmarried couple & 656 & $30(4.87)$ & 17.16 & & $6.18-47.66$ \\
\hline \multicolumn{6}{|l|}{ Social support } \\
\hline High & 529 & $13(2.24)$ & 1.00 & \multirow[t]{3}{*}{.71} & - \\
\hline Medium & 438 & $11(2.9)$ & 1.30 & & $.37-4.57$ \\
\hline Low & 499 & $22(1.77)$ & 0.79 & & $.23-2.71$ \\
\hline \multicolumn{6}{|c|}{ Lifetime stressors before September 11} \\
\hline $0-1$ & 806 & $18(1.22)$ & 1.00 & \multirow[t]{3}{*}{.11} & - \\
\hline $2-3$ & 419 & $12(2.93)$ & 2.44 & & $.62-9.37$ \\
\hline $4+$ & 269 & $16(4.60)$ & 3.90 & & $1.10-13.81$ \\
\hline \multicolumn{6}{|c|}{ Life stressors 12 months before September 11} \\
\hline 0 & 867 & $17(1.40)$ & 1.00 & \multirow[t]{3}{*}{.27} & - \\
\hline 1 & 398 & $14(3.08)$ & 2.23 & & $.66-7.55$ \\
\hline $2+$ & 229 & $15(3.94)$ & 2.88 & & $.75-11.11$ \\
\hline
\end{tabular}

${ }^{a}$ Weighted prevalences; see Methods.

${ }^{b}$ Includes divorced, separated, widowed, or never married.

Table 4 shows a final multivariable model predicting new onset of drinking problems at 6 months after September 11. The adjusted covariates associated (i.e., $p<.10$ ) with new onset drinking problems were age less than 25 years old $(p=.01)$, marital status (never married or unmarried couple) $(p<.001)$, and having experienced a panic attack in the hours after the September 11 attacks.

\section{Discussion}

Our results suggest that $2.2 \%$ of over six million adults living in NYC reported drinking problems in the 6 months after September 11 that were not present before September 11; this corresponds to approximately 130,000 adults. Although our earlier results suggest that increased substance use may be observed in the aftermath of a disaster and that it may frequently co-occur with PTSD and depression (Vlahov et al., 2002), these results go beyond mere frequency of substance use and suggest an increase in drinking problems which also tend to co-occur with PTSD and of depression.

Substance use and drinking problems have been previously described in various groups after disasters and after traumatic events, although not consistently (Abrahams et al., 1976; Breslau et al., 2003; Joseph et al., 1993; Logue et al., 2979; Op Den Velde et al., 2002). However, different time frames of assessment, different measures of substance use and a 
Table 3

Incident problem drinking by exposure to the events of September 11 among adult New York City residents categorized as nonproblem drinkers before September 11, 2001

\begin{tabular}{|c|c|c|c|c|c|}
\hline & $\begin{array}{c}\text { Total } \\
\text { sample } \mathrm{n}\end{array}$ & $\begin{array}{c}\text { New drinking } \\
\text { problem after } \\
\text { September } 11 \\
\mathrm{n}\left(\%^{a}\right)\end{array}$ & OR & $\begin{array}{c}\text { Chi } \\
\text { square } \\
p \text { value }\end{array}$ & $95 \% \mathrm{CI}$ \\
\hline Total & 1,494 & $46(2.21)$ & & & \\
\hline \multicolumn{6}{|c|}{ Panic attack } \\
\hline No & 1,230 & $24(1.56)$ & 1.00 & \multirow[t]{2}{*}{.02} & - \\
\hline Yes & 264 & $22(5.3)$ & 3.53 & & $1.23-10.10$ \\
\hline \multicolumn{6}{|c|}{ Live below 14th St } \\
\hline No & 852 & $19(2.18)$ & 1.00 & \multirow[t]{2}{*}{.15} & - \\
\hline Yes & 642 & $27(3.59)$ & 1.67 & & $.83-3.35$ \\
\hline \multicolumn{6}{|c|}{ Saw September 11 attacks in person } \\
\hline No & 878 & $24(2.24)$ & 1.00 & \multirow[t]{2}{*}{.53} & - \\
\hline Yes & 605 & $21(1.54)$ & .67 & & $.20-2.29$ \\
\hline \multicolumn{6}{|c|}{ Fear of personal injury or death } \\
\hline No & 1,058 & $23(1.94)$ & 1.00 & \multirow[t]{2}{*}{.29} & - \\
\hline Yes & 366 & $19(3.38)$ & 1.77 & & $.62-5.06$ \\
\hline \multicolumn{6}{|c|}{ Friend or relative killed } \\
\hline No & 1,288 & $40(2.37)$ & 1.00 & \multirow[t]{2}{*}{.48} & - \\
\hline Yes & 206 & $6(1.43)$ & .60 & & $.14-2.49$ \\
\hline \multicolumn{6}{|c|}{ Lost possessions } \\
\hline No & 1,141 & $39(2.04)$ & 1.00 & \multirow[t]{2}{*}{.10} & - \\
\hline Yes & 82 & $7(7.83)$ & 4.07 & & $.77-21.53$ \\
\hline \multicolumn{6}{|c|}{ Involved in rescue effort } \\
\hline No & 1,311 & $39(2.04)$ & 1.00 & \multirow[t]{2}{*}{.40} & - \\
\hline Yes & 182 & $7(3.95)$ & 1.98 & & $.40-9.72$ \\
\hline \multicolumn{6}{|c|}{ Lost job due to September 11 attacks } \\
\hline No & 1,392 & $39(1.96)$ & 1.00 & \multirow[t]{2}{*}{.06} & - \\
\hline Yes & 92 & $7(7.08)$ & 3.81 & & $.92-15.72$ \\
\hline \multicolumn{6}{|c|}{ Directly affected by September 11 attacks $^{b}$} \\
\hline No & 1,024 & $26(1.72)$ & 1.00 & \multirow[t]{2}{*}{.18} & - \\
\hline Yes & 470 & $20(3.46)$ & 2.04 & & $.72-5.78$ \\
\hline
\end{tabular}

${ }^{a}$ Weighted prevalences; see Methods.

${ }^{b}$ Includes persons who were in the World Trade Center on September 11, 2001, who were injured in the attacks, who had a friend or relative killed, lost or damaged possessions, lost a job, or who were involved in rescue effort.

predominant focus on direct survivors make it difficult to compare the results from our study with these previous studies. Although a few studies have shown that degree of event exposure is associated with a greater degree of substance use after disasters, problems with uniformly measuring disaster exposure make it difficult to draw conclusions about the relative increase in substance use within exposure gradients (Beckham et al., 1997; Green et al., 1985). Studies of uniformed personnel who have significant exposure to disasters and traumatic events show higher rates of problems with alcohol use than in the general 
Table 4

Final multivariable adjusted ORs for new-onset problem drinking after September 11, 2001 among adult New York City residents without problem drinking in the month before September 11, 2001

\begin{tabular}{|c|c|c|c|}
\hline Characteristic & OR & CI & $p$ value \\
\hline \multicolumn{4}{|l|}{ Age } \\
\hline $18-24$ & 1.00 & - & \multirow[t]{6}{*}{.01} \\
\hline $25-34$ & .43 & $(.12,1.57)$ & \\
\hline $35-44$ & .26 & $(.05,1.49)$ & \\
\hline $45-54$ & .28 & $(.05,1.65)$ & \\
\hline $55-64$ & .50 & $(.06,3.81)$ & \\
\hline $65+$ & .01 & $(.00, .13)$ & \\
\hline \multicolumn{4}{|l|}{ Low income } \\
\hline$\$ 20,000+$ & 1.00 & - & \multirow[t]{2}{*}{.25} \\
\hline$<\$ 20,000$ & 1.97 & $(.62,6.25)$ & \\
\hline \multicolumn{4}{|l|}{ Marital status } \\
\hline Married & 1.00 & - & \multirow[t]{3}{*}{$<.001$} \\
\hline Single $^{a}$ & 4.07 & $(.82,20.24)$ & \\
\hline Unmarried couple & 12.52 & $(3.59,43.63)$ & \\
\hline \multicolumn{4}{|l|}{ Panic attack } \\
\hline No & 1.00 & - & \multirow[t]{2}{*}{.03} \\
\hline Yes & 3.96 & $(1.15,13.66)$ & \\
\hline \multicolumn{4}{|l|}{ Lost possessions } \\
\hline No & 1.00 & - & \multirow[t]{2}{*}{.13} \\
\hline Yes & 3.68 & $(.69,19.63)$ & \\
\hline \multicolumn{4}{|c|}{ Lost job due to September 11 attacks } \\
\hline No & 1.00 & - & \multirow[t]{2}{*}{.47} \\
\hline Yes & 1.80 & $(.36,8.92)$ & \\
\hline
\end{tabular}

${ }^{a}$ Includes divorced, separated, widowed, or never married.

population (Boxer and Wild, 1993). In our study, those with drinking problems were not linked to variables that measured direct exposure to the disaster; the data suggest that drinking problems after a disaster may be more diffuse in the population than previously appreciated. We are not aware of other studies that have reported data about patterns of treatment-seeking in NYC before and after the attacks of September 11 nor about changes in emergency room visits related to use of substances. Such inquiry may be fruitful areas of future research.

Epidemiological evidence suggests that men are more likely to have lifetime diagnoses of substance use dependence than women (Grant, 1997; Hezler et al., 1991; Kessler et al., 1994). However, there is little convincing evidence that changes in substance use after disasters is different between men and women (Stewart, 1996). In our study of substance use frequency after September 11 we did note that men were significantly more likely to report increases in alcohol use after the attacks (Vlahov et al., 2002). In the current analysis we noted no significant gender differences for problem drinking, although women were somewhat more likely than men to report new-onset drinking problems. Similarly, although data suggest that race/ethnicity may be related to the likelihood of posttrauma 
psychopathology, there is little evidence for a relation between differential rates of substance use in racial/ethnic groups postdisaster (Kluka et al., 1990). In particular, Asians were least likely to demonstrate increases in alcohol in our earlier report, but in this analysis they tended to have somewhat higher rates of drinking problems (Vlahov et al., 2002). This finding may represent a racial/ethnic genetic variable on tolerance for alcohol among Asians. We note that our observation of a greater likelihood of alcohol drinking among members of an unmarried couple is intriguing. We are not aware of prior comparable analyses that might explicate this association, and any explanation at this juncture would be speculative. Further work is indicated to determine whether this group is at particularly high risk of substance use problems after a disaster.

The observations we draw from this study must be interpreted with caution. Our surveys measured PTSD, depression, and substance use concurrently; thus temporality in the associations cannot be established. These data do not measure abuse or dependence but rather problem drinking. The CAGE questionnaire has been used in a number of clinical and population based studies with comparability across mode of administration and has generally had good sensitivity and specificity (Cherpitel, 1999, 2002; Fiellin et al., 2000; Kraus and Augustine, 2001). However, the CAGE is typically asked to assess lifetime alcohol problems rather than alcohol problems in a limited time frame, such as that used in this analysis. As such, it is plausible that our use of the CAGE provides a conservative estimate of the true scope of alcohol use problems in the 6-month period of interest. Although we have seen an increase in alcohol consumption frequency in our earlier report and in drinking problems with these data, it does not necessarily follow that there may be an increase in alcohol dependence using strict clinical criteria (Vlahov et al., 2002). For example, after the Oklahoma City bombing, studies of first responders noted no new onset of psychiatrist diagnoses of alcohol dependence even among those with PTSD (North et al., 2002a). However, postdisaster alcohol use disorders and drinking to cope were associated with indicators of poorer functioning (North et al., 2002b). Because of the magnitude of the September 11 attacks, rates of substance use increase and rates of new-onset drinking problems in more circumscribed disasters may be expected to be lower than those observed in this study. As a last note on this matter, we note that the CAGE is not typically used to assess problem drinking after traumas or disaster and as such, inference drawn from the CAGE in this context must be drawn cautiously.

Additional concerns relate to context, recall, and nonresponse. The lack of an association with variables measuring direct exposure might be due to context surrounding the disaster. At the time this study was done, NYC residents were on heightened alert with ongoing concern about possible further terrorist attacks. The observed rates of problem drinking may have also been influenced by other events, including the concomitant evolving economic recession which added to stressors faced by NYC residents at the time. This may mean that a degree of the observed increase in substance use and alcohol problems was attributable to other stressors in addition to the events of September 11 themselves. We collected data using anonymous telephone interviews, raising the alternate possibility of under-reporting of substances used. It also is possible that respondents' recall may have been less accurate when asked about substance use and problem drinking before September 11 than it was when asked about substance use in the period before the survey (Loftus et al., 1983). Likewise, because our surveying took place over a 3-month interval, this time period may have represented an interval of 6 to 9 months for different respondents that might have affected responses. Baseline prevalence of alcohol use from this survey, however, is comparable with national estimates which reduces this concern (NHSDA, 2000). Finally, nonresponse bias is possible in this sample, as with all other general population samples. 
However, we note that recent reports suggest a weak association between response rates and epidemiological estimates (Keeter et al., 2000; Mariolis, 2002). The reader is referred to a previous publication for a full discussion of the implications of survey response rates in this study (Galea et al., 2004). Ultimately we note that this study was not designed to fully assess the individual, network, or contextual determinants of substance use and misuse after this disaster. Increasingly we are recognizing that features of the recovery environment are important determinants of mental health and other consequences of disasters. Further work is needed to clarify how the complex, dynamic, postdisaster environment influences response, resilience, and potential coping mechanisms in the post-disaster period.

The finding of new-onset drinking problems in a representative sample of adults 6 months after September 11 in conjunction with our earlier reports of an early and persistent increase in alcohol use is in contrast with earlier studies that have suggested that alcohol problems are not a feature of the postdisaster period. Although our study cannot definitely link an increase in drinking problems with direct exposure to the disaster, the results suggest that after a disaster, a link between drinking problems and PTSD or depression should be assessed.

\section{Acknowledgments}

Supported by grants from the United Way of New York City, The New York Community Trust, the Met Life Foundation, the National Institute on Drug Abuse (R01 DA14219-01S1), and the National Institute on Mental Health (R01 MH66081). We thank Dr. Donald Hoover for statistical assistance. We are indebted to all participants who were involved in the study.

\section{Glossary}

Depression: A common mental disorder that presents with depressed mood, loss of interest or pleasure, feelings of guilt or low self-worth, disturbed sleep or appetite, low energy, and poor concentration. Such problems can become chronic or recurrent and lead to significant impairments in an individual's daily responsibilities.

Disasters: Mass traumatic events that involve multiple persons and are frequently accompanied by loss of property and economic hardship on a large scale.

Posttraumatic Stress Disorder: An anxiety disorder caused by en extremely stressful event (e.g., assault, rape, military combat, flood, hurricane, terrorist attack, technological disasters etc.).

Substance Abuse: A destructive pattern of substance use leading to clinically significant (social, occupational, medical) impairment or distress. Symptoms include suffering from withdrawal symptoms within several hours to a few days after a reduction in the amount of the substance taken over a prolonged period of time, taking substances to relieve withdrawal symptoms, inability to cut down or quite use of substance(s), and excessive time spent in trying to obtain substance(s).

\section{RÉSUMÉ}

Des études récents ont montré un incrément dans la consumation de l'alcool à New York City dans les mois qui ont suivi les attaques terroristes du 11 septembre; jusqu'à présent il n'y a eu aucun étude qui documentait des changements dans le problème de l'alcoolisme. En 2002, on a enquêté un sondage téléphonique avec des nombres aléatoires des habitants de New York City. Cette enquête nous a fourni une évaluation de la fréquence du problème 
de l'alcoolisme parmi les résidents de New York City six mois après le 11 septembre comparée avec les six mois avant le 11 septembre. Parmi les 1570 adultes, la fréquence du problème de l'alcoolisme était 3,7\% dans les six mois avant le 11 septembre et 4,2\% dans les six mois après le 11 septembre. La fréquence du problème de l'alcoolisme parmi ceux qui n'avaient aucun problème de l'alcoolisme avant le 11 septembre était 2,2\%. Ilétait bien possible que les personnes avec des problèmes de l'alcoolisme annonçassent des symptômes compatibles avec un état de stress post-traumatique plus que ceux sans problèmes de l'alcoolisme (17,4\% vs. $0,4 \%$ parmi ceux sans problèmes de l'alcoolisme et $1,4 \%$ parmi ceux qui ne consomme jamais de l'alcool) et la dépression (23,5\% vs 5,6\% vs. $4,9 \%$, respectivement) après le 11 septembre. Après un désastre, un rapport entre le problème de l'alcoolisme et l'état de stress post-traumatique ou la dépression doit être faite.

\section{RESUMEN}

Aunque estudios recientes han demostrado aumentos de la ingestión de alcohol en la ciudad de Nueva York después de los ataques terroristas del 11 de septiembre, hasta ahora cambios en beber-problemas no han sido documentados por estudios clínicos. Como punto de estimar la prevalencia de beber-problemas, en dos mil dos se realizaron un total de 1570 entrevistas telefónicas a hogares Neoyorquinos utilizando el sistema Random Digit Dial (RDD: Marcación Telefónica Aleatoria) los seis meses después del 11 de septiembre comparado a los seis meses antes del 11 de septiembre. En los seis meses antes del 11 de septiembre beber-problemas aparecieron en un 3,7\% de la población del estudio, y en un 4,2\% de esa población después. La incidencia de beber-problemas entre ellos sin beber-problema previo antes del 11 de septiembre es un 2,2\% de la población. Esas personas con su primer índice de beber-problema eran mas probable a reportar síntomas del trastorno de estrés postraumático (PTSD) comparados con ellos sin beber-problemas (17,4\% vs. 0,4\% y 1,4 en los que no beben), y síntomas de la depresión (23,5\% vs. $5,6 \%$ vs. $4,9 \%$, respectivamente) después del 11 de Septiembre. Después de un desastre, la conexión entre beber-problemas y PTSD o la depresión debe de ser analizada.

\section{THE AUTHORS}

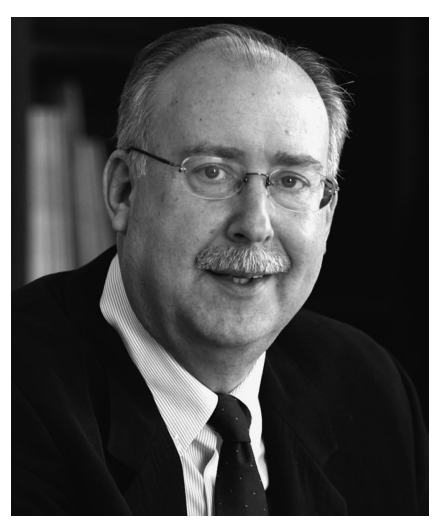

David Vlahov, Ph.D., is an epidemiologist with expertise in the conduct of large population-based cohorts, focusing on infectious disease, drug use, and mental health. He has studied drug use and its consequences for the past 20 years. 

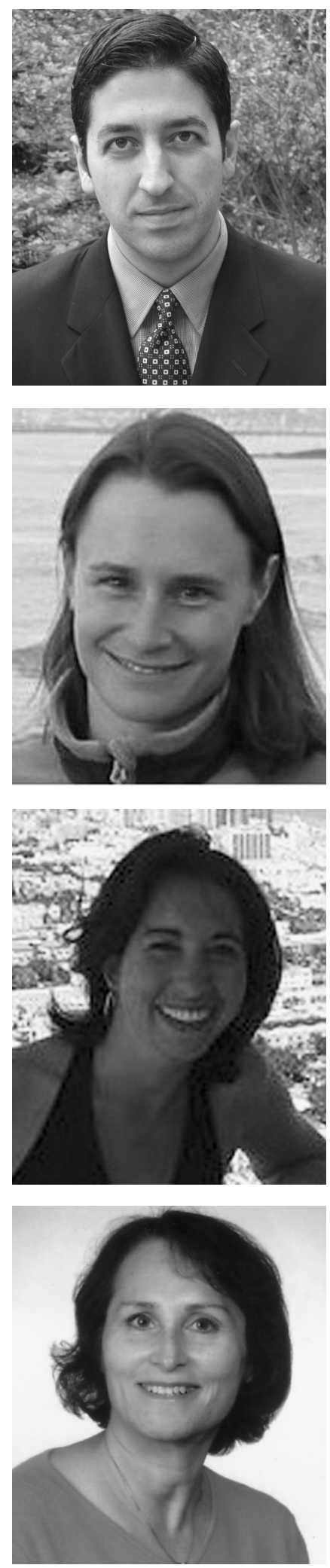

Sandro Galea, M.D., Dr. P.H., is Associate Professor of Epidemiology at the University of Michigan School of Public Health and an investigator at the Center for Urban Epidemiologic Studies at the New York Academy of Medicine. His primary research interests are the social and economic production of mental health; he has an abiding interest in the health consequences of collectively experienced traumatic events.

Jennifer Ahern, M.P.H., is Senior Research Analyst at the Center for Urban Epidemiologic Studies at the New York Academy of Medicine and at the University of Michigan School of Public Health.

Sasha Rudenstine, B.A., is Project Director at the Center for Urban Epidemiologic Studies, at the New York Academy of Medicine. In that capacity she has served as the Coordinator of the Disaster Research Education and Mentoring Center.

Heidi Resnick, Ph.D., is Professor in the Department of Psychiatry at the Medical University of South Carolina in Charleston, SC. Her primary research interests concern the mental health consequences of trauma. 

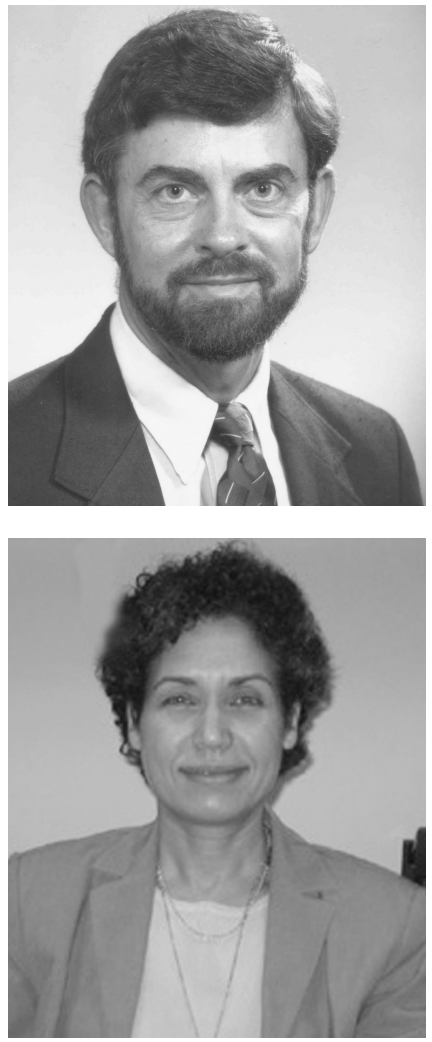

Dean G. Kilpatrick, Ph.D., is Professor of Clinical Psychology and Director of the National Crime Victims Research and Treatment Center at the Medical University of South Carolina in Charleston, SC. His primary research interests include measuring the prevalence of rape, other violent crimes and potentially traumatic events, and assessing the mental health impact of such events.

Rosa M. Crum, M.D., M.H.S., is an Associate Professor of Epidemiology at the Johns Hopkins University Bloomberg School of Public Health and has joint appointments in the Departments of Psychiatry and Behavioral Sciences, and Mental Health. She is also a faculty member in the Welch Center for Prevention, Epidemiology, and Clinical Research. Her research has focused on the epidemiology, prevention, and clinical treatment of alcohol abuse and alcoholism and the cooccurrence with other drug disorders and psychiatric conditions.

\section{References}

Abrahams, M. J., Price, J., Whitlock, F. A., Williams, G. (1976). The Brisbane Floods, January 1974: their impact on health. Med. J. Aust. 2:936-939.

Acierno, R. A., Kilpatrick, D. G., Resnick, H. S., Saunders, B. E., Best, C. L. (1996). Violent assault, posttraumatic stress disorder, and depression. Risk factors for cigarette use among adult women. Behav. Modif. 20(4):363-384.

American Psychiatric Association. (1995). Diagnostic and Statistical Manual of Mental Disorders. 4th ed. Washington, DC: American Psychiatric Association.

Beckham, J. C., Kirby, A. C., Feldman, M. E., Hertzberg, M. A., Moore, S. D., Crawford, A. L., Davidson, J. R., Fairbank, J. A. (1997). Prevalence and correlates of heavy smoking in Vietnam veterans with chronic posttraumatic stress disorder. Addict. Behav. 22(5):637-647.

Blanchard, E. B., Hickling, E. J., Forneris, C. A., Taylor, A. E., Buckley, T. C., Loos, W. R., Jaccard, J. (1997). Prediction of remission of acute posttraumatic stress disorder in motor vehicle accident victims. J. Trauma Stress 10(2):215-234.

Blanchard, E. B., Hickling, E. J., Vollmer, A. J., Loos, W. R., Buckley, T. C., Jaccard, J. J. (1995). Short-term follow-up of post-traumatic stress symptoms in motor vehicle accident victims. Beh. Res. Therapy 33:369-377.

Boxer, P. A., Wild, D. (1993). Psychological distress and alcohol use among fire fighters. Scand. J. Work. Environ. Health 19(2):121-125.

Breslau, N., Davis, G. C., Schultz, L. R. (2003). Posttraumatic stress disorder and the incidence of nicotine, alcohol, and other drug disorders in persons who have experienced trauma. Arch. Gen. Psychiatry 60:289-294. 
Buchsbaum, D. G., Buchanan, R. G., Centor, R. M., Schnoll, S. H., Lawton, M. J. (1991). Screening for alcohol abuse using CAGE scores and likelihood ratios. Ann. Intern. Med. 115:774777 .

Centers for Disease Control (1989). Diagnostic Interview Schedule. Atlanta, GA: CDC.

Chan, A. W., Pristach, E. A., Welte, J. W. (1994). Detection by the CAGE of alcoholism or heavy drinking in primary care outpatients and the general population. J. Substance. Abuse 6:123135.

Cherpitel, C. J. (1990). Screening for alcohol problems in the U.S. general population: a comparison of the CAGE and TWEAK by gender, ethnicity, and services utilization. J. Stud. Alcohol 60:705-711.

Cherpitel, C. J. (2002). Screening for alcohol problems in the U.S. general population: comparison of the CAGE, RAPS4, and RAPS4-QF by gender, ethnicity, and service utilization. Rapid Alcohol Problems. Screen. Alcohol. Clin. Exp. Res. 26:1686-1691.

Deering, C. G., Glover, S. G., Ready, D., Eddleman, H. C., Alarcon, R. D. (1996). Unique patterns of comorbidity in posttraumatic stress disorder from different sources of trauma. Compr. Psychiatry 37:336-346.

Fiellin, D. A., Reid, M. C., O’Connor, P. G. (2000). Screening for alcohol problems in primary care: systematic review. Arch. Intern. Med. 160:1977-1989.

Freedy, J., Kilpatrick, D., Resnick, H. (1993). Natural disasters and mental health: theory, assessment, and intervention. J. Soc. Behav. Personality. 8(5):49-103. [Special Issue]

Galea, S., Ahern, J., Resnick, H., Kilpatrick, D., Bucuvalas, M., Gold, J., Vlahav, D. (2002a). Psychological sequelae of the September 11 terrorist attacks in New York City. N. Engl. J. Med. 346(13):982-987.

Galea, S., Ahern, J., Resnick, H., Kilpatrick, D., Bucuvalas, M., Gold, J., Vlahov, D. (2003). Prevalence, progression, and correlates of post-traumatic stress disorder after the September 11 attacks in New York City. Am. J. Epidemiol. 158:514-524.

Galea, S., Resnick, H., Ahern, J., Gold, J., Bucuvalas, M., Kilpatrick, D., Stuber, J., Vlahov, D. (2002b). Posttraumatic stress disorder in Manhattan, New York City, after the September 11th terrorist attacks. J. Urban. Health 79(3):340-353.

Galea, S., Vlahov, D., Resnick, H., Kilpatrick, D., Bucuvalas, M. J., Morgan, M. D., Gold, J. (2002c). An investigation of the psychological effects of the September 11, 2001, attacks on New York City: developing and implementing research in the acute postdisaster period. CNS Spectr. 7(8):593-596.

Galea, S., Vlahov, D., Tracy, M., Hoover, D., Resnick, H., Kilpatrick, D. G. (2004). Hispanic ethnicity and post-traumatic stress disorder after a disaster: evidence from a general population survey after September 11. Ann. Epidemiol 14:520-531.

Gleser, G., Green, B. (1981). Prolonged Psychosocial Effects of Disaster: A Study of Buffalo Creek. New York: Academic Press.

Grant, B. F. (1997). Prevalence and correlates of alcohol use and DSM-IV alcohol dependence in the United States: results of the National Longitudinal Alcohol Epidemiologic Survey. J. Stud. Alc. 58:464-473.

Green, B. L. (1991). Evaluating the Effects of Disasters. J. Consult. Clin. Psychol. 3(4):538-546.

Green, B. L., Grace, M. C., Gleser, G. (1985). Identifying survivors at risk: long-term impairment following the Beverly Hills Supper Club fire. J. Consult. Clin. Psychol. 53:672-678.

Helzer, J. E., Burnam, A., McEvoy, L. T. (1991). Alcohol abuse and dependence. In: Robins, L. N., Regier, D. A., eds. Psychiatric Disorders in America: The Epidemiologic Catchment Area Study. New York: The Free Press/MacMillan, pp. 81-115.

Jacobsen, L. K., Southwick, S. M., Kosten, T. R. (2001). Substance use disorders in patients with posttraumatic stress disorder: a review of the literature. Am. J. Psychiatry 158(8):1184-1190.

Joseph, S., Yule, W., Williams, R., Hodgkinson, P. (1993). Increased substance use in survivors of the Herald of Free Enterprise disaster. Br. J. Med. Psychol. 66(Pt 2):185-191.

Keeter, S., Miller, C., Kohut, A., Groves, R. M., Presser, S. (2000). Consequences of reducing nonresponse in a national telephone survey. Public. Opin. Q 64(2):125-148. 
Kessler, R. C., McGonagle, K. A., Zhao, S., Nelson, C. B., Hughes, M., Eshleman, S., Wittchen, H. U., Kendler, K. S. (1994). Lifetime and 12-month prevalence of DSM-III-R psychiatric disorders in the United States. Results from the National Comorbidity Survey. Arch. Gen. Psychiatry 51(1):8-19.

Kessler, R. C., Sonnega, A., Bromet, E., Hughes, M., Nelson, C. B. (1995). Posttraumatic stress disorder in the National Comorbidity Survey. Arch. Gen. Psychiatry. 52(12):1048-1060.

Kilpatrick, D., Resnick, H., Freedy, J. (1998). The posttraumatic stress disorder field trial: evaluations of the PTSD construct — criteria A through E. In: Widiger, T., Frances, A., Pincus, H., eds. DSM IV Sourcebook. 4th ed. Washington, DC: American Psychiatric Association Press, pp. 803844.

Kilpatrick, D. G., Ruggiero, K. J., Acierno, R., Saunders, B. E., Resnick, H. S., Best, C. L. (2003). Violence and risk of PTSD, major depression, substance abuse/dependence, and comorbidity: results from the National Survey of Adolescents. J. Consult. Clin. Psychol. 71(4):692-700.

Kraus, L., Augustin, R. (2001). Measuring alcohol consumption and alcohol related problems: comparison of responses from self-administered questionnaires and telephone interviews. Addiction 96:459-471.

Kulka, R., Schlenger, W., Fairbank, J., Weiss, D. (1990). Trauma and the Vietnam War generation: Report of findings from the National Vietnam Veterans Readjustment Study. London: Bunner/Mazel.

Loftus, E. F., Marburger, W. (1983). Since the eruption of Mt St Helens, has anyone beaten you up? Improving the accuracy of retrospective reports with landmark events. Mem. Cognit 11:114120.

Logue, J. N., Hansen, H., Struening, E. (1979). Emotional and physical distress following Hurricane Agnes in Wyoming Valley of Pennsylvania. Public. Health. Rep. 94:495-502.

Mariolis, P. (May 2002). Response Rates and Data Accuracy. Nashville, TN: American Association of Public Opinion Research.

National Household Survey on Drug Abuse. (2000). Main Findings, 1998. Substance Abuse and Mental Health Services Administration, Rockville, MD: Department of Health and Human Services.

Norris, F. H. (1992). Epidemiology of trauma: frequency and impact of different potentially traumatic events on different demographic groups. J. Consult. Clin. Psychol 60(3):409-418.

Norris, F. H., Friedman, M. J., Watson, P. J. (2002a). 60,000 disaster victims speak: Part II. Summary and implications of the disaster mental health research. Psychiatry 65(3):240-260.

Norris, F. H., Friedman, M. J., Watson, P. J., Byrne, C. M., Diaz, E., Kaniasty, K. (2002b). 60,000 disaster victims speak: Part I. An empirical review of the empirical literature, 1981-2001. Psychiatry 65(3):207-239.

North, C. S., Tivis, L., McMillen, J. C., Pfefferbaum, B., Cox, J., Spitznagel, E. L., Bunch, K., Schorr, J., Smith, E. M. (2002b). Coping, functioning, and adjustment of rescue workers after the Oklahoma City bombing. J. Trauma. Stress 15:171-175.

North, C. S., Tivis, L., McMillen, J. C., Pfefferbaum, B., Spitznagel, E. L., Cox, J., Nixon, S., Bunch, K. P., Smith, E. M. (2002a). Psychiatric disorders in rescue workers after the Oklahoma City bombing. Am. J. Psychiatry 159:857-859.

Op Den Velde, W., Aarts, P. G., Falger, P. R., Hovens, J. E., Van Duijn, H., De Groen, J. H., Van Duijn, M. A. (2002). Alcohol use, cigarette consumption and chronic post-traumatic stress disorder. Alcohol 37:355-361.

Poulin, C., Webster, I., Single, E. (1997). Alcohol disorders as indicated by the CAGE questionnaire. CMAJ 157:1529-1535.

Resnick, H. S., Kilpatrick, D. G., Dansky, B. S., Saunders, B. E., Best, C. L. (1993). Prevalence of civilian trauma and Posttraumatic Stress Disorder in a representative national survey of women. J. Consult. Clin. Psychol 61:984-991.

Schlenger, W. E., Caddell, J. M., Ebert, L., Jordan, B. K., Rourke, K. M., Wilson, D., Thalji, L., Dennis, J. M., Fairbank, J. A., Kulka, R. A. (2002). Psychological reactions to terrorist attacks: findings from the National Study of Americans' Reactions to September 11. JAMA 288(5):581-588. 
Schuster, M. A., Stein, B. D., Jaycox, L., Collins, R. L., Marshall, G. N., Elliott, M. N., Zhou, A. J., Kanouse, D. E., Morrison, J. L., Berry, S. H. (2001). A national survey of stress reactions after the September 11, 2001, terrorist attacks. N. Engl. J. Med. 345(20):1507-1512.

Shah, B., Barnewll, B., Bieler, G. (1997). SUDAAN User's Manual, Release 7.5. Research Triangle Park, NC: Research Tringle Institute.

Sherbourne, C. D., Stewart, A. L. (1991). The MOS social support survey. Soc. Sci. Med. 32(6):705714.

Silver, R. C., Holman, E. A., McIntosh, D. N., Poulin, M., Gil-Rivas, V. (2002). Nationwide longitudinal study of psychological responses to September 11. JAMA 288(10):1235-1244.

Smith, E. M., North, C. S., McCool, R. E., Shea, J. M. (1990). Acute postdisaster psychiatric disorders: identification of persons at risk. Am. J. Psychiatry 147(2):202-206.

Stewart, S. H. (1996). Alcohol abuse in individuals exposed to trauma: a critical review. Psychol. Bull. 120(1):83-112.

Stewart, S. H., Pihl, R. O., Conrod, P. J., Dongier, M. (1998). Functional associations among trauma, PTSD, and substance-related disorders. Addict. Behav. 23(6):797-812.

U.S. Bureau of the Census (2000). Census summary tape, file 3A (STF3A). Washington DC: U.S. Dept of Commerce.

Vlahov, D., Galea, S., Ahern, J., Resnick, H., Kilpatrick, D. (2004). Sustained increased consumption of cigarettes, alcohol, and marijuana among Manhattan residents after September 11, 2001. Am. J. Public. Health 94(2):253-254.

Vlahov, D., Galea, S., Resnick, H., Ahern, J., Boscarino, J. A., Bucuvalas, M., Gold, J., Kilpatrick, D. (2002). Increased Consumption of Cigarettes, Alcohol, and Marijuana among Manhattan Residents after the September 11 Terrorist Attacks. Am. J. Epidemiol. 555:988-996. 